Вивчено особливості одержання покриттів на вуглецевій, конструкційній сталі Ст 3 при дифузійній металізацї одночасному насиченні стали бором, хромом $і$ алюмінієм (борохромоалітування) без використання спеціальної термічної обробки. За допомогою методу симплексних решіток встановлено основні склади порошкових сумішей, які дають отримати на поверхні вуглецевої сталі боридні структури підвищеної твердості, фази твердого розчину бору, хрому та алюмінію y $\boldsymbol{F e}_{\alpha}$ та прогнозовану глибину поверхневого шару. Встановлені характерні особливості формування мікротвердості поверхневого шару покриттів залежно від складу насичуючої суміші. Встановлений важливий фактор впливу алюмінію на мікротвердість поверхневого шару у багатокомпонентних системах. Його присутність сприяє утворенню твердих розиинів. Отримані нові дані про формування поверхневих шарів при насиченні сталі бором, хромом $i$ алюмінієм $i$ певні умови одержання иарів високої твердості й високої пластичності. Знайдені оптимальні області формування покриттів різної структури та глибини методом симплексного планування. В якості факторів оптимізації були використані відносні площини, зайняті боридами й твердим розчином, а також глибина поверхневих шарів. Наочно показано, як змінюється структура поверхневих шарів складовими насичуючих сумішей. Графічні залежності боридної фази, фази твердого розчину й глибини шару від складу насичуючої суміші, при дифузійній металізації (борохромоалітування) дозволяють удосконалювати процес із метою одержання на поверхні вуглецевої сталі покриття з підвищеною зносостійкістю

Ключові слова: хіміко-термічна оброб$\kappa a$, дифузійна металізація, структура, мікротвердість, зносостійкість, боридна фаза залежно від кількісних співвідношень між

\section{DETERMINATION OF THE PECULIARITIES OF OBTAINING COATINGS OF DIFFERENT HARDNESS ON STRUCTURAL STEEL AT DIFFUSION METALIZATION}

\author{
O. Markov
}

Doctor of Technical Sciences, Professor, Head of Department Department of Computerized Design and Modeling Processes and Machines* Y. Diachenko $\mathrm{PhD}$

Department of Technologies and Equipment of Foundry* E-mail: dyachenko.yurij.1978@gmail.com

L. Aliieva

Doctor of Technical Sciences, Associate Professor Department of Metal Forming*

S. Zharikov

$\mathrm{PhD}$

Department Equipment and Technologies of Welding Production*

N. Hrudkina

$\mathrm{PhD}$

Department of Higher Mathematics*

V. Bondarenko

$\mathrm{PhD}$, Associate Professor**

M. Pohorielov Senior Lecturer**

*Donbass State Engineering Academy Akademichna str., 72, Kramatorsk, Ukraine, 84313 **Department of General Technical Disciplines,

Life Safety and Automotive

Donbass State Pedagogical University G. Batiuka str., 19, Slavyansk, Ukraine, 84116

Copyright (C) 2019, O. Markov, Y. Diachenko, L. Aliieva, S. Zharikov, N. Hrudkina, V. Bondarenko, M. Pohorielov

\section{Introduction}

The processes of complex saturation of products during chemical-thermal treatment have recently been increasingly used in industry, compared with single-component processes [1]. This is caused by the fact that, during single-component saturation, structures are formed on the surface of metal products that determine only a narrow range of properties in the product [2]. Carrying out complex alloying saturation by successive multiple single-component saturation, for exam- ple, boron, and then chromium and aluminum, significantly increases energy consumption [3]. At the same time, the use of alloyed, high-carbon steels, as well as alternative multicycle processes of chemical-thermal and subsequent heat treatment, such as cementation with subsequent hardening and tempering of low-carbon steels, reduces the profitability of production [4].

It is known that the general saturation of the metal surface simultaneously with boron, chromium and aluminum makes it possible to obtain layers of various hardness, including 
high hardness, on the surface of metal products, which is able to impart cutting properties to products [5]. This trend in science and industry can be traced in connection with the shortage and high cost of tool steels [6]. It follows that with surface saturation of carbon steels it is possible to obtain a cutting tool [7]. However, cutting tools in many cases require not only surface hardness, but also the hardness over the tool cross section eliminates deformation of the cutting edge [8]. The level of this hardness can be different depending on the type of tool and the conditions of its operation [9]. Therefore, the solution to the problem of obtaining tools based on carbon, structural steels with deposited wear-resistant coatings requires special studies.

Factors that make it difficult to solve the problems posed are the indefinite types of structures, the depth and hardness of the surface layers during diffuse metallization to obtain various hardnesses on structural steel. There is no information on the application of the composition of the powder mixture to obtain coatings on structural steel with the corresponding properties. As a result, it is complicated to obtain high-quality diffuse coatings on structural steel.

Therefore, the problem of obtaining coatings of a given structure, depth and different hardness on structural steel during diffuse metallization is relevant, requiring comprehensive study and analysis.

\section{Literature review and problem statement}

In [10], it is noted that among a large number of coating methods, a promising method is the method of obtaining diffusion layers in powder mixtures. The authors of the work emphasize that the advantages of the method are simplicity and accessibility of application, equipment, eliminates the violation of environmental safety of the environment, and also eliminates the use of special equipment.

Based on an analysis of the data [11], it was shown that boron, chromium-plated and aluminized coatings have high wear, heat and corrosion resistance, respectively. But boron coatings have low ductility, low heat and corrosion resistance. Chromium plated coatings have a small depth and low affinity for the base metal. Aluminizes coatings do not provide indicators of wear resistance. This fact limits the use of single-component coatings in production, especially when it comes to the durability of machine parts and tools in conditions of impact-abrasive wear.

In [12], methods for producing coatings using simultaneously two components of a saturating mixture are experimentally investigated. It is established that two-component coatings expand the field of application of the layers, for example, Alloying with chromium borides reduces the fragility of the latter. However, this is not enough, since boron chromium coatings have low heat resistance, which makes operation at high temperatures impossible.

In a study [13] with the introduction of the process of diffusion metallization of carbon steel, the effect of chromium and aluminum on the properties of the surface layer was shown. It is proved that the diffuse process of chromium aluminizing provides high indices of scale and erosion resistance of products operating in aggressive environments. However, abrasion resistance remains low.

In [14], the effect of boron and aluminum is studied while saturating the surface of carbon steel on the indicators of heat resistance and corrosion. The authors of the work found that boron aluminizing provides heat resistance to products, but does not protect carbon steels from corrosion in aqueous solutions of salts, alkalis and acids. Therefore, two-component coatings are of limited use in industry.

According to the research results, the authors of [15] found that the introduction of the third component in the composition of the powder mixture will allow the formation of layers with the necessary properties on the surface of the products. The most promising is the process of complex saturation with boron, chromium and aluminum, when it is possible to minimize the energy costs of the process and get the maximum effect from improving product quality.

An analysis of the literature makes it possible to determine that the results of boron chromium aluminizing are known that are insufficiently substantiated theoretically and practically for widespread adoption in industry. Today it is impossible to clearly identify the types of structures and the depth of the surface layers that provide high levels of hardness of the coating on products from structural steels. Lack of information on the use of the composition of the boron chromium aluminizing mixture to obtain the predicted coating with the desired properties. Lack of systematically established research results hinders the application in industry of optimal technologies for complex saturation with boron, chromium and aluminum. Therefore, it is necessary to improve and study the features of the process of diffusion metallization of carbon, structural steel in powder mixtures by the composition of the saturating mixture to obtain structures and coatings of different depths with the predicted hardness of the surface layer.

\section{The aim and objectives of research}

The aim of research is identification of the features of obtaining coatings on structural steel to obtain the predicted structures of different hardness and depth during boron chromium aluminizing.

To achieve the aim, the following objectives are set:

- identify the types of structures and their hardness depending on the composition of the saturating mixture on structural steel during boron chromium aluminizing;

- establish the optimal formation region of boron chromium aluminizing coatings of various structures and depths depending on the composition of the saturating mixture.

\section{Materials and methods of research for producing coatings of different hardness on structural steel during diffuse metallization}

When choosing the elements that saturate the steel surface, let's proceed from the considerations of obtaining high hardness of the surface layer due to phases based on chemical compounds, expanding the possibilities of using coatings without special heat treatment. In addition, let's took into account the fact that the coating should have not only wear resistance, but also have high corrosion resistance when working with aqueous emulsion coolants and increased resistance to oxidation when the cutting edge is heated.

The studies are carried out in accordance with the planning matrix by the method of simplex lattices. Saturating the components, let's vary within $0 \ldots 25 \% \quad \mathrm{~B}_{4} \mathrm{C}, 0 \ldots 25 \%$ $\mathrm{Cr}_{3} \mathrm{C}_{2}, 0 \ldots 25 \% \mathrm{Al}, 43 \ldots 68 \% \mathrm{Al}_{2} \mathrm{O}_{3}$, with a constant content 
of $7 \% \mathrm{NaCl}$ - to activate the diffusion metallization process. Heating is carried out at a temperature of $1000{ }^{\circ} \mathrm{C}$ for $5 \mathrm{~h}$, followed by cooling of the container with the furnace (which lasted 15 hours). The coating was applied to samples of steel St 3, suggesting in the future the possibility of making large taps from it for processing aluminum alloys.

The layer structure is investigated using a MIM-8 metallographic microscope and a PMT-3 microhardness measuring device. Chemical etching of microsections in a $4 \%$ solution of nitric acid in ethanol and thermal digestion are used. Using thermal digestion, upon heating the surface of the microsection in the furnace after diffusion metallization, color oxidation of the phases and the base metal of the surface of the microsection occurs for several minutes.

\section{Identification of types of structures and their rigidity on structural steel, depending on the composition of the saturating mixture during boron chromium aluminizing}

To identify the main types of structures that form on the surface of structural steel and analyze their hardness depending on the composition of the saturating mixture, a number of studies of boron chromium aluminizing process are carried out (Table 1). In the course of the research, it is revealed that on the surface of structural steel St 3 coatings of three types are formed. The first type is boride, characterized by high hardness $\left(H_{100} 12870 \mathrm{MPa}\right)$ after saturation in mixtures containing $25 \% \mathrm{~B}_{4} \mathrm{C}$ or contain, in addition to $25 \%$ $\mathrm{B}_{4} \mathrm{C}$, chromium carbide $\left(\mathrm{Cr}_{3} \mathrm{C}_{2}\right)$ in an amount of not more than $12.5 \%$ (Table 1 ). When boride is saturated in mixture No. 1, 12, 13, the surface layer consists of two zones: the first zone is porous, light in color, the second zone is dense, straw-colored (Fig. 1). A similar structure of the surface layer is also observed after saturation in mixtures No. 10 and 11 (Table 1).

After saturation in mixture No. 2, 3, 6, 7, 8, 25, the structure of the surface layer corresponds to the structure of boride and aluminizing layers obtained upon saturation in one-component mixtures, which are confirmed by published data [1].

When saturated in two-component mixtures (compositions No 3...5, 17, 20, 23), a change in the contents of $\mathrm{Cr}_{3} \mathrm{C}_{2}$ and $\mathrm{Al}$ powder within the indicated limits (Table 1) does not affect the structure of the surface layer. It consists of two zones: upper loose and lower dense, which is a solid solution of chromium and aluminum in $\mathrm{Fe}_{\alpha}$ (compositions No. 3...5) or boron and aluminum in $\mathrm{Fe}_{\alpha}$ (compositions No. 17, 20, 23) - this is the second type of structure.
It is possible to assume that in the presence of aluminum, boron and chromium do not form independent phases, but are part of the solid solution. The indicated type of coating differs from the first type in low microhardness indices of $H_{100} 3090 \ldots 2770 \mathrm{MPa}$ (Table 1).

The complete absence of aluminum (compositions No. 1, 10, 11) contributes to the appearance of borides having a high hardness of $H_{100} 12870 \mathrm{MPa}$ (Fig. 1). Moreover, stably high values of hardness of borides $H_{100} 14800 \ldots 13500 \mathrm{MPa}$ are provided when the $\mathrm{Cr}_{3} \mathrm{C}_{2}$ content is not more than $12.5 \%$ (compositions No. 12, 13).

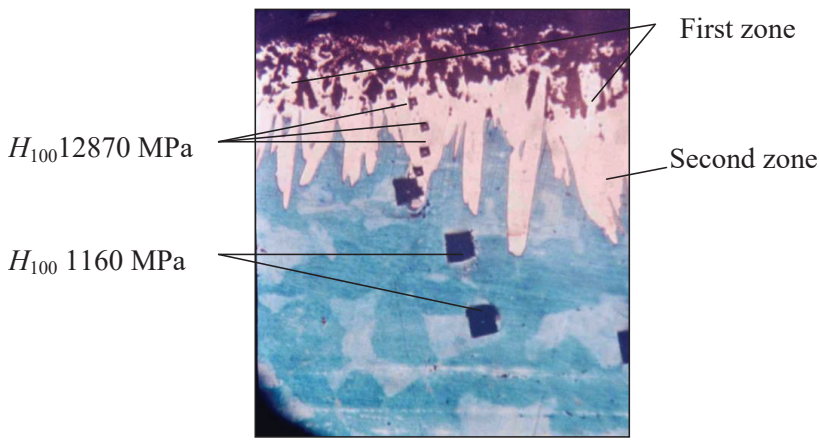

Fig. 1. Microstructure of the surface layer of steel St 3 after diffusion metallization, $\times 100$

Table 1

Effect of saturating mixture composition on microhardness and layer depth

\begin{tabular}{|c|c|c|c|c|c|c|c|c|c|c|}
\hline \multirow{2}{*}{$\begin{array}{c}\text { No. of } \\
\text { compo- } \\
\text { sition }\end{array}$} & \multicolumn{5}{|c|}{ Composition content, \% } & \multirow{2}{*}{$\begin{array}{c}\text { Depth of } \\
\text { the layer, } \\
\text { mm }\end{array}$} & \multicolumn{4}{|c|}{$\begin{array}{l}\text { Microhardness } \\
\text { of the layer } H_{100}, \mathrm{MPa}\end{array}$} \\
\hline & $\mathrm{B}_{4} \mathrm{C}$ & $\mathrm{Cr}_{3} \mathrm{C}_{2}$ & $\mathrm{Al}$ & $\mathrm{Al}_{2} \mathrm{O}_{3}$ & $\mathrm{NaCl}$ & & 1 zone & 2 zone & 3 zone & $\begin{array}{l}\text { (basic } \\
\text { metal }\end{array}$ \\
\hline 1 & 25 & 0 & 0 & 68 & 7 & 0.2 & 12,870 & 12,870 & 10,400 & 1,130 \\
\hline 2 & 0 & 0 & 25 & 68 & 7 & 0.45 & 8,500 & 4,210 & 2,540 & 9,80 \\
\hline 3 & 0 & 25 & 25 & 43 & 7 & 0.3 & 2,900 & 3,090 & 2,290 & 1,050 \\
\hline 4 & 0 & 18.75 & 25 & 49.25 & 1 & 0.25 & 3,090 & 3,090 & 1,700 & 1,480 \\
\hline 5 & 0 & .5 & 25 & 55.5 & 7 & 0.28 & 2,290 & 3,190 & 1,800 & 1,130 \\
\hline 6 & 0 & 6.25 & 25 & 61.75 & 7 & 25 & 2,770 & 3,500 & 150 & 1,130 \\
\hline 7 & 6.25 & 0 & 18.75 & 68 & 7 & 0.25 & 4,880 & 3,190 & 3,190 & 980 \\
\hline 8 & 12.5 & 0 & 12.5 & 68 & 7 & 0.2 & 2,730 & 2,730 & 1,870 & 1,000 \\
\hline 9 & 18.75 & 0 & 6.25 & 68 & 7 & 0.3 & 2,990 & 3,190 & 2,290 & 1,180 \\
\hline 10 & 25 & 25 & 0 & 43 & 7 & 0.1 & 6,700 & 12,870 & 10,400 & 1,560 \\
\hline 11 & 25 & 18.75 & 0 & 49.25 & 7 & .10 & 6,860 & 10,400 & 11,660 & 1,420 \\
\hline 12 & 25 & 12.5 & 0 & 55.5 & 7 & 0 & 13,500 & 13,500 & 11,660 & 1,560 \\
\hline 13 & 25 & 6.25 & 0 & 61.75 & 7 & 0.2 & 14,800 & 13,000 & 12,870 & 1,560 \\
\hline 14 & 6.25 & 25 & 18.75 & 43 & 7 & 0.25 & 1,870 & 3,090 & 1,970 & 1,050 \\
\hline 15 & 12.5 & 25 & 12.5 & 43 & 7 & 0.2 & 2,540 & 3,050 & 2,060 & 980 \\
\hline 16 & 18.75 & 25 & 6.25 & 43 & 7 & 0.15 & 2,440 & 3,190 & 1,700 & 980 \\
\hline 17 & 6.25 & 18.75 & 18.75 & 49.25 & 7 & 0.2 & 2,850 & 3,190 & 1,700 & 1,210 \\
\hline 18 & 12.5 & 18.75 & 12.5 & 49.25 & 7 & 0.2 & 2,610 & 3,140 & 1,700 & 1,360 \\
\hline 19 & 18.75 & \begin{tabular}{|l|}
18.75 \\
\end{tabular} & 6.25 & 49.25 & 7 & 0.13 & 2,440 & 3,140 & 1,870 & 1,260 \\
\hline 20 & 6.25 & 12.5 & 18.75 & 55.5 & 7 & 0.3 & 2,770 & 2,850 & 2,060 & 1,130 \\
\hline 21 & 12.5 & 12.5 & 12.5 & 55.5 & 7 & 0.2 & 2,290 & 3,190 & 2,060 & 1,050 \\
\hline 22 & 18.75 & 12.5 & 6.25 & 55.5 & 7 & 0.2 & 2,440 & 2,850 & 1,700 & 1,130 \\
\hline 23 & 6.25 & 6.25 & 18.75 & 61.75 & 7 & 0.25 & 3,660 & 2,290 & 1,870 & 1,420 \\
\hline 24 & 12.5 & 6.25 & 12.5 & 61.75 & 7 & 0.25 & 2,540 & 2,440 & 2,230 & 1,210 \\
\hline 25 & 18.75 & 6.25 & 6.25 & 61.75 & 7 & 0.2 & 2,060 & 2,060 & 2,060 & 1,130 \\
\hline
\end{tabular}


With a higher $\mathrm{Cr}_{3} \mathrm{C}_{2}$ content, the boride hardness decreases $H_{100} 12870 \ldots 10400 \mathrm{MPa}$, which can be explained by the dissolution of chromium in them. Most likely, with a significant $\mathrm{Cr}_{3} \mathrm{C}_{2}$ content of $25 \%$ (composition No. 10), chromium, dissolving in borides, forms a solid solution of iron, contains boron and chromium (Table 1). This is evidenced by the fact that part of the borides, which did not turn into a solid solution, remains in the surface layer in depth. The hardness of such borides is $H_{100} 10400 \mathrm{MPa}$ and they are located close to the border with the base metal - this is the third type of structure.

In the other mixtures studied (compositions No. 14-25), the microhardness of the coating of the surface layer does not differ significantly from $H_{100} 3190 \ldots 2060 \mathrm{MPa}$ and corresponds to the second type of structure (solid solution). Especially close is the microhardness of the surface layer after saturation in mixtures (compositions No. 22, 24, 25) containing all three components: $\mathrm{B} 4 \mathrm{C}, \mathrm{Cr}_{3} \mathrm{C}_{2}$ and $\mathrm{Al}$ powder (Table 1). It should be noted that $\mathrm{Al}$, which is part of the powder mixture, does not contribute to the formation of coatings of high hardness.

Thus, it is found that in the process of diffusion metallization (boron chromium aluminizing), depending on the composition of the powder mixture on the surface of structural steel, three types of layers are formed: the first is a boride (boride phase) of high hardness; the second is a solid solution (solid solution phase) of low hardness; the third is borides located in a solid solution of variable stiffness.

\section{Establishment of optimal areas for the formation of boron chromium aluminizing coatings of various structures and depths depending on the composition of the saturating mixture}

To search for optimal solutions for the formation of coatings of various structures and depths, the simplex method of experiment planning is used.

As the optimization factors, let's use the relative planes occupied by borides and solid solution, as well as the depth of the surface layers (Table 2).

Simplex method planning matrix

\begin{tabular}{|c|c|c|c|c|c|c|c|c|c|c|c|}
\hline \multirow{2}{*}{ No. } & \multicolumn{3}{|c|}{ Plan matrix } & \multicolumn{5}{|c|}{ Mixture compositions, \% } & \multicolumn{3}{|c|}{ Optimization factors } \\
\cline { 2 - 13 } & $X 1$ & $X 2$ & $X 3$ & $\mathrm{~B}_{4} \mathrm{C}$ & $\mathrm{Al}$ & $\mathrm{Cr}_{3} \mathrm{C}_{2}$ & $\mathrm{Al}_{2} \mathrm{O}_{3}$ & $\mathrm{NaCl}$ & $\begin{array}{c}\text { coride } \\
\text { phase, \% } \\
\text { \%ig. 3) }\end{array}$ & $\begin{array}{c}\text { solid } \\
\text { solution } \\
\text { phase, \% } \\
\text { (Fig. 4) }\end{array}$ & $\begin{array}{c}\text { Layer } \\
\text { depth, } \\
\text { mm } \\
\text { (Fig. 5) }\end{array}$ \\
\hline 1 & 1 & 0 & 0 & 25 & 0 & 0 & 68 & 7 & 24.71 & 0 & 0.2 \\
\hline 2 & 0 & 1 & 0 & 25 & 0 & 25 & 43 & 7 & 5.11 & 14 & 0.1 \\
\hline 3 & 0 & 0 & 1 & 0 & 25 & 0 & 68 & 7 & 0 & 49.75 & 0.45 \\
\hline 4 & 0.5 & 0.5 & 0 & 25 & 0 & 12.5 & 55.5 & 7 & 23.74 & 0 & 0.2 \\
\hline 5 & 0.5 & 0 & 0.5 & 12.5 & 12.5 & 0 & 68 & 7 & 0.2 & 47.5 & 0.2 \\
\hline 6 & 0 & 0.5 & 0.5 & 12.5 & 12.5 & 12.5 & 55.5 & 7 & 0 & 38.08 & 0.2 \\
\hline 7 & 0.75 & 0.25 & 0 & 25 & 0 & 6.25 & 61.75 & 7 & 7.92 & 20.1 & 0.2 \\
\hline 8 & 0.25 & 0.75 & 0 & 25 & 0 & 18.75 & 49.25 & 7 & 4.24 & 13.1 & 0.15 \\
\hline 9 & 0.75 & 0 & 0.25 & 18.75 & 6.25 & 0 & 68 & 7 & 1.45 & 36.83 & 0.3 \\
\hline 10 & 0.25 & 0 & 0.75 & 6.25 & 18.75 & 0 & 68 & 7 & 0.15 & 40.03 & 0.25 \\
\hline 11 & 0 & 0.75 & 0.25 & 18.75 & 6.25 & 18.75 & 49.25 & 7 & 0.18 & 24.27 & 0.13 \\
\hline 12 & 0 & 0.25 & 0.75 & 6.25 & 18.75 & 6.25 & 61.75 & 7 & 0 & 39.13 & 0.25 \\
\hline 13 & 0.5 & 0.25 & 0.25 & 18.75 & 6.25 & 6.25 & 61.75 & 7 & 0.73 & 36.53 & 0.2 \\
\hline 14 & 0.25 & 0.5 & 0.25 & 18.75 & 6.25 & 12.5 & 55.5 & 7 & 1.47 & 32.63 & 0.2 \\
\hline 15 & 0.25 & 0.25 & 0.5 & 12.5 & 12.5 & 6.25 & 61.75 & 7 & 0.49 & 36.95 & 0.25 \\
\hline
\end{tabular}

A polynomial of the fourth degree is used as a model. The coordinates of the plan points are shown in Fig. 2.

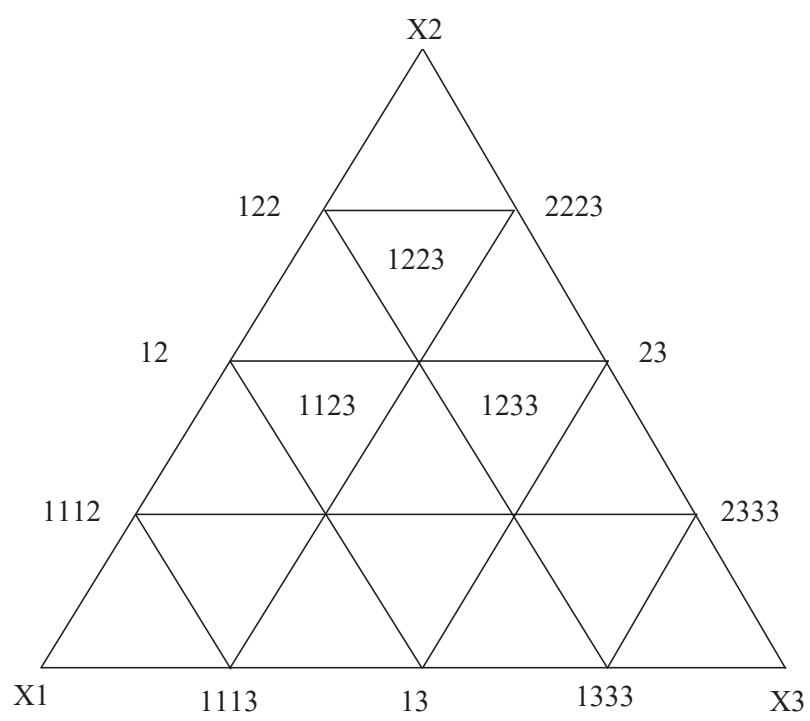

Fig. 2. Simplex lattice of the fourth degree

The equation of the fourth degree, which connects all the values of the factors with the optimization parameters, has the form:

$$
\begin{aligned}
& y=\beta_{1} x_{1}+\beta_{2} x_{2}+\beta_{3} x_{3}+\beta_{12} x_{1} x_{2}+\beta_{13} x_{1} x_{3}+ \\
& +\beta_{23} x_{2} x_{3}+\gamma_{12} x_{1} x_{2}\left(x_{1}-x_{2}\right)+\gamma_{13} x_{1} x_{3}\left(x_{1}-x_{3}\right)+ \\
& +\gamma_{23} x_{2} x_{3}\left(x_{2}-x_{3}\right)+\delta_{12} x_{1} x_{2}\left(x_{1}-x_{2}\right)^{2}+ \\
& +\delta_{13} x_{1} x_{3}\left(x_{1}-x_{3}\right)^{2}+\delta_{23} x_{2} x_{3}\left(x_{2}-x_{3}\right)^{2}+ \\
& +\beta_{1123} x_{1}^{2} x_{2} x_{3}+\beta_{1223} x_{1} x_{2}^{2} x_{3}+\beta_{1233} x_{1} x_{2} x_{3}^{2},
\end{aligned}
$$

Table 2 where

$$
\begin{aligned}
& \beta_{1}=y_{1} ; \beta_{2}=y_{2} ; \beta_{3}=y_{3} ; \\
& \beta_{12}=4 y_{12}-2 y_{1}-2 y_{2} ; \\
& \beta_{13}=4 y_{13}-2 y_{1}-2 y_{3} ; \\
& \beta_{23}=4 y_{23}-2 y_{2}-2 y_{3} ; \\
& \gamma_{12}=\frac{8}{3}\left(-y_{1}+2 y_{1112}-2 y_{1222}+y_{2}\right) ; \\
& \gamma_{13}=\frac{8}{3}\left(-y_{1}+2 y_{1113}-2 y_{1333}+y_{3}\right) ; \\
& \gamma_{23}=\frac{8}{3}\left(-y_{2}+2 y_{2223}-2 y_{2333}+y_{3}\right) ; \\
& \delta_{12}=\frac{8}{3}\left(-y_{1}+4 y_{1112}-2 y_{1222}+y_{2}\right) ; \\
& \delta_{13}=\frac{8}{3}\left(-y_{1}+4 y_{1113}-6 y_{1333}+y_{3}\right) ; \\
& \delta_{23}=\frac{8}{3}\left(-y_{2}+4 y_{2223}-6 y_{2333}+y_{3}\right) ;
\end{aligned}
$$




$$
\begin{aligned}
& \beta_{1123}=32\left(3 y_{1123}-y_{1223}-y_{1233}\right)+ \\
& +\frac{8}{3}\left(6 y_{1}-y_{2}-y_{3}\right)-16\left(y_{12}+y_{13}\right)- \\
& -\frac{16}{3}\left(5 y_{1112}+5 y_{113}-3 y_{1222}-3 y_{1333}-y_{2223}-y_{2333}\right) ; \\
& \beta_{1223}=32\left(3 y_{1223}-y_{1123}-y_{1233}\right)+ \\
& +\frac{8}{3}\left(6 y_{2}-y_{1}-y_{3}\right)-16\left(y_{12}+y_{23}\right)- \\
& -\frac{16}{3}\left(5 y_{1222}+5 y_{2223}-3 y_{1222}-3 y_{2333}-y_{2223}-y_{1333}\right) ; \\
& \beta_{1233}=32\left(3 y_{1233}-y_{1123}-y_{1223}\right)+ \\
& +\frac{8}{3}\left(6 y_{3}-y_{1}-y_{3}\right)-16\left(y_{13}+y_{23}\right)- \\
& -\frac{16}{3}\left(5 y_{1333}+5 y_{2333}-3 y_{1112}-3 y_{2223}-y_{1112}-y_{1222}\right) ;
\end{aligned}
$$

The graphical dependence of the boride phase on the composition of the saturating mixture is shown in Fig. 3.

According to the Table 2, the highest concentration of the boride phase ( 24.71 and $23.74 \%$ ) is formed on the surface of steel St 3, when saturated in a mixture of No. 1 and No. 4, which consist of $25 \% \mathrm{~B}_{4} \mathrm{C}, 68 \% \mathrm{Al}_{2} \mathrm{O}_{3}, 7 \% \mathrm{NaCl}$ and $25 \%$ $\mathrm{B}_{4} \mathrm{C}, 12,5 \% \mathrm{Cr}_{3} \mathrm{C}_{2} \quad 55,5 \% \mathrm{Al}_{2} \mathrm{O}_{3}, 7 \% \mathrm{NaCl}$, respectively. The smallest amount of the boride phase $(0.15$ and $0.18 \%)$ is formed in a mixture of No. 10 and No. 11, the composition is $6.25 \% \mathrm{~B}_{4} \mathrm{C}, 18.75 \% \mathrm{Cr}_{3} \mathrm{C}_{2}, 68 \% \mathrm{Al}_{2} \mathrm{O}_{3}, 7 \% \mathrm{NaCl}$ and $18.75 \% \mathrm{~B}_{4} \mathrm{C}, 6,25 \% \mathrm{Al}, 18.75 \% \mathrm{Cr}_{3} \mathrm{C}_{2}, 49.25 \% \mathrm{Al}_{2} \mathrm{O}_{3}$,
$7 \% \mathrm{NaCl}$, respectively (Table 2). A decrease in the supplier of boron and an increase in the supplier of aluminum and chromium ensure the absence of borides in the surface layer (mixture No. 3, 6, 12, Table 2).

The graphical dependence of the phase of the solid solution of the composition of the saturating mixture is shown in Fig. 4.

The largest amount of solid solution (49.75 and $47.5 \%$ ) is formed upon saturation in a mixture of No. 3 and No. 5, which consist of $25 \% \mathrm{Al}, 68 \% \mathrm{Al}_{2} \mathrm{O}_{3}, 7 \% \mathrm{NaCl}$, and $12.5 \% \mathrm{~B}_{4} \mathrm{C}$, $12.5 \% \mathrm{Al}, 68 \% \mathrm{Al}_{2} \mathrm{O}_{3}, 7 \% \mathrm{NaCl}$, respectively. The smallest amount of the solid solution phase corresponds to the composition of mixtures No. 1 and No. 4 (Table 2), in which aluminum is absent, as well as in mixture No. 8 , where the chromium concentration varies from 0 to $18.75 \%$ with a constant amount of $\mathrm{B}_{4} \mathrm{C} 25 \%$. A decrease in the concentration of chromium in saturating mixture No. 1 from 6.25 to $0 \%$ with a constant amount of $25 \% \mathrm{~B}_{4} \mathrm{C}$ leads to the disappearance of the solid solution and the appearance of borides (Table 2).

The greatest depth of the surface layer $(0.45 \mathrm{~mm})$ is formed upon saturation in mixture No. 3 (Table 2), in which aluminum has the highest concentration - $25 \%$ (Fig. 5).

A decrease in the amount of aluminum from $25 \%$ to $6.25 \%$ and an increase in boron from 0 to $18.75 \%$ reduces the depth of the surface layer, which is $0.3 \mathrm{~mm}$ (mixture No. 9 of Table 2). When saturated in powder mixtures No. 12 and No. 15 of $6.25 \% \mathrm{~B}_{4} \mathrm{C}, 6.25 \% \mathrm{Cr}_{3} \mathrm{C}_{2}, 18.25 \% \mathrm{Cr}_{3} \mathrm{C}_{2}, 12.5 \% \mathrm{Al}$, $61.75 \% \mathrm{Al}_{2} \mathrm{O}_{3}, 7 \% \mathrm{NaCl} 75 \% \mathrm{Al}, 61.75 \% \mathrm{Al}_{2} \mathrm{O}_{3}, 7 \% \mathrm{NaCl}$ and $12.5 \% \mathrm{~B}_{4} \mathrm{C}$, respectively, on the samples of steel St 3 a diffuse layer is formed with a depth of $0.25 \mathrm{~mm}$. The smallest layer depth $(0.1 \mathrm{~mm})$ is formed on the surface of the steel when saturated in powder mixture No. 2, composition: $25 \% \mathrm{~B}_{4} \mathrm{C}$, $25 \% \mathrm{Cr}_{3} \mathrm{C}_{2}, 43 \% \mathrm{Al}_{2} \mathrm{O}_{3}$ and activator $7 \% \mathrm{NaCl}$ (Table 2 ).

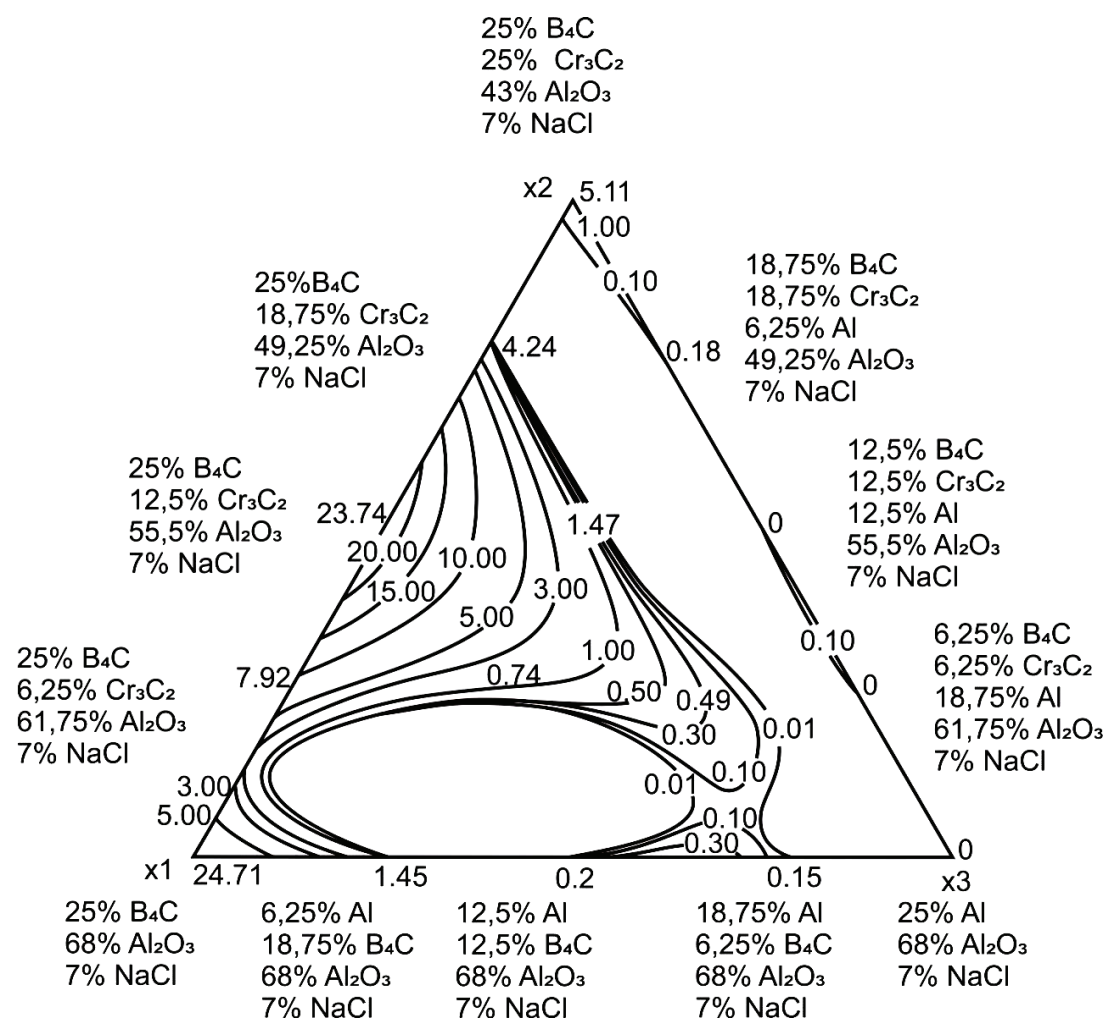

Fig. 3. Regularities of the quantitative change in the boride phase (\%) in the surface layer, depending on the composition of the saturating mixture during diffuse metallization (boron chromium aluminizing) (Table 2) 
$25 \% \mathrm{~B}_{4} \mathrm{C}$

$25 \% \mathrm{Cr}_{3} \mathrm{C}_{2}$

$43 \% \mathrm{Al}_{2} \mathrm{O}_{3}$

$7 \% \mathrm{NaCl}$

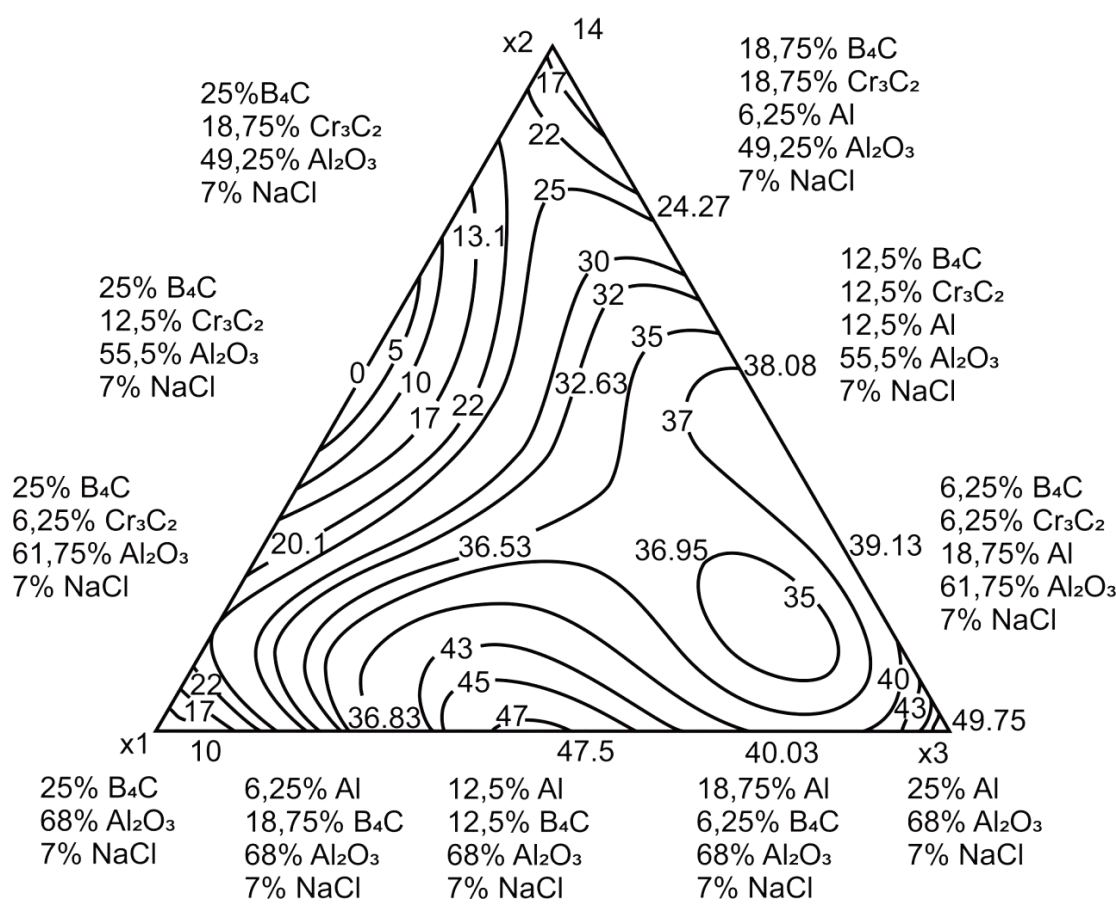

Fig. 4. Regularities of the quantitative change in the phase of the solid solution (\%) in the surface layer, depending on the composition of the saturating mixture, during diffuse metallization (boron chromium aluminizing) (Table 2)

$25 \% \mathrm{~B}_{4} \mathrm{C}$

$25 \% \mathrm{Cr}_{3} \mathrm{C}_{2}$

$43 \% \mathrm{Al}_{2} \mathrm{O}_{3}$

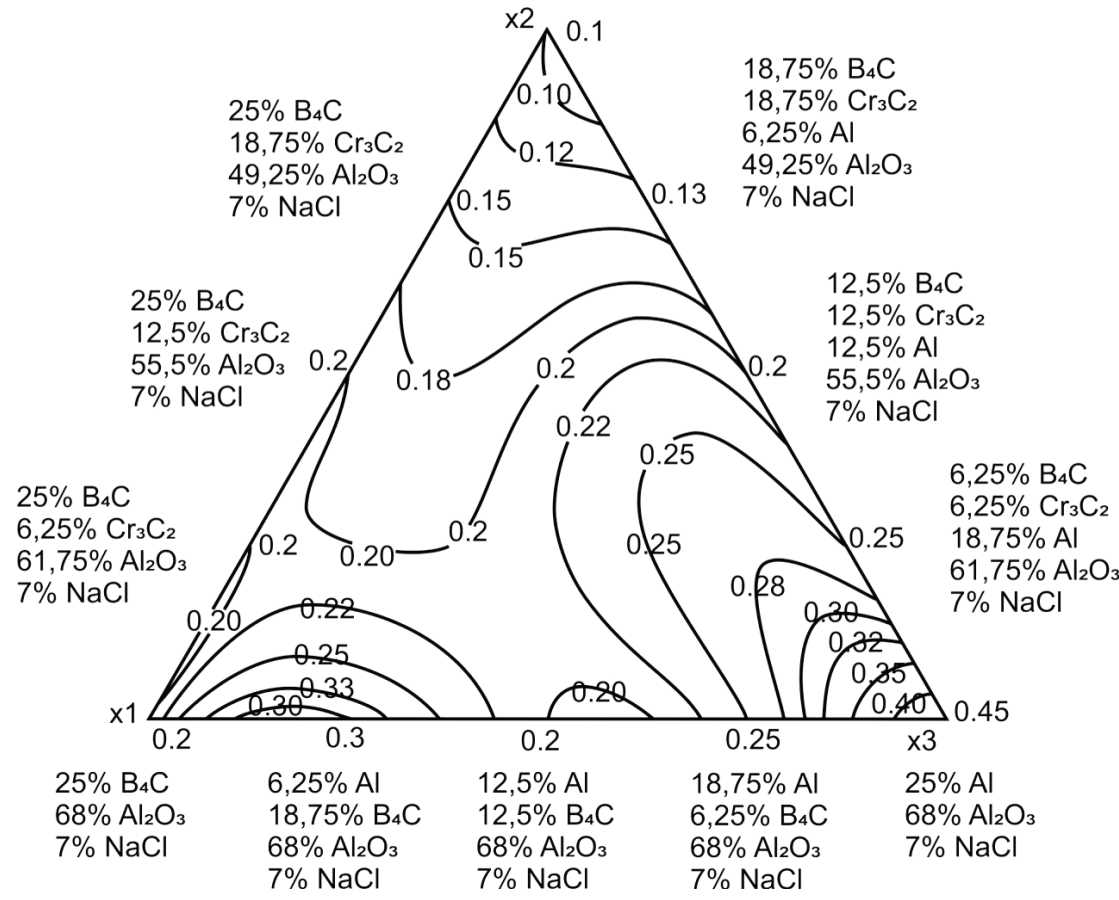

Fig. 5. Regularities of changes in depth $(\mathrm{mm})$ of the surface layer depending on the composition of the saturating mixture during diffuse metallization (boron chromium aluminizing) (Table 2)

\section{Discussion of the results of} coatings of different hardness on structural steel during diffuse metallization

The study of coatings of different hardness on structural steel during saturation in powder mixtures during diffuse metallization is carried out. The obtained results allow to determine the effect of the composition of saturating mixtures on the structure formation, depth, rigidity and wear resistance of the surface layers during diffuse metallization of carbon steel, structural steel St 3:

- complex saturation of three components simultaneously in a container with a melting shutter provides significant time savings. Previously, saturations were carried out sequentially, first with two, and then with one component. This required a significant process time and an increase in energy consumptions;

- method of steel saturation in powder mixtures differs from other methods of diffusion metallization in the simplicity of the process without the use of special, expensive equipment. Another method of diffusion metallization requires the use of industrial frequency currents, gas and other harmful and dangerous environments;

- boron chromium aluminizing carbon steel allows to obtain coatings with different surface hardness. Depending on the composition of the powder mixture, using the simplex method, solid solution coatings with a hardness of $H_{100} 2500 \ldots 3500 \mathrm{MPa}$ (Table 1) and boride coatings with a hardness of $H_{100}$ 12000-14000 MPa (Fig. 1) are obtained on the steel surface;

- the laws of changes in the structure, depth and hardness of the surface layers are studied depending on the composition of the saturating mixture (Table 1). Graphical dependences of the boride phase (Fig. 3), the phase of the solid solution (Fig.4) and the layer depth (Fig. 5) on the composition of the saturating mixture (Table 2) are constructed. Previously, it is impossible to obtain coatings of the desired structure and depth on the surface of boron chromium aluminizing steel. The construction of graphical dependencies made it possible to obtain predicted coatings on structural steel.

The limitations of complex saturation of structural steel during diffuse metallization include the following:

- thoroughly prepare the components of the saturating mixture and exclude the ingress of oxygen during 
the diffusion metallization process under the fusible plug and prevent sintering of the powder mixture. To do this, it is necessary to accurately measure the amount of the powder mixture based on the volume of the samples or metal products in this mixture;

- limiting the process of boron chromium aluminizing in powder mixtures in a container with a melting shutter according to the dimensions of the metal product. To solve the problem of saturation of the surface of dimensional parts simultaneously with boron, chromium and aluminum, such as the impossibility of manufacturing large containers and the use of expensive heating equipment, it is possible to propose a diffusion metallization process using pastes or coatings based on boron, chromium and aluminum;

- the use of wear-resistant coatings obtained after boron chromium-alumina in powder mixtures on structural steel is advisable in conditions of abrasive friction. With shock-abrasive friction, coatings that have high hardness and low ductility will collapse and reduce wear resistance.

In this work, boron chromium aluminizing of coatings on structural steel St 3 is studied using the process of diffusion metallization in powder mixtures. The components of the powder mixture were changed in accordance with the planning matrix of the simplex method. The activator $(\mathrm{NaCl}-7 \%)$ and the process temperature $\left(1000^{\circ} \mathrm{C}\right)$ remain unchanged. Therefore, the unresolved issues remain the determination of the effect of temperature and the use of other activators of the saturating powder mixture on the formation of coatings during boron chromium aluminizing.

In this work, let's use carbon structural steel St 3, which belongs to the low-carbon group of steels. The use of mediumcarbon and low-alloy steels may give further development to the study.
In order to find optimal solutions using quantitative metallographic analysis of structural components to obtain reliable research results, it is necessary to observe the quality surface of microsections and a clear image of the microstructure of steel samples.

\section{Conclusions}

1. The process of diffusion metallization (boron chromium aluminizing), depending on the concentration of elements in the composition of the mixtures, forms three types of layers on the surface of carbon steel: the first - boride (boride phase); the second is a solid solution (solid solution phase); the third is borides located in a solid solution. Each layer has special properties that during operation of boron chromium aluminizing products will meet certain requirements.

An important factor is established for the effect of aluminum on the microhardness of the surface layer during boron chromium aluminizing. An increase in the aluminum concentration from $18.7 \%$ to $25 \%$, which is part of the saturating mixture during boron chromium aluminizing, increases the depth of the surface layer and the formation of a phase of a solid solution. A decrease in the concentration of aluminum from $25 \%$ to $6.2 \%$ in boron chromium aluminizing mixtures promotes the formation of chromium alloyed high hardness borides.

2. The graphical dependences of the boride phase, solid solution phase and layer depth on the composition of the saturating mixture during diffuse metallization (boron chromium aluminizing) allow to improve the process in order to obtain coatings with a predicted structure, depth and hardness on the surface of carbon steel.

\section{References}

1. Karunanayake, G., Ng, Y.-L., Knowles, J. C., Delgado, A. H. S., Young, A. M., Gulabivala, K., Nazhat, S. N. (2019). The effect of $\mathrm{NaOCl}$ and heat treatment on static and dynamic mechanical properties and chemical changes of dentine. Journal of the Mechanical Behavior of Biomedical Materials, 97, 330-338. doi: https://doi.org/10.1016/j.jmbbm.2019.05.042

2. Chien, Y.-C., Yang, T.-C., Hung, K.-C., Li, C.-C., Xu, J.-W., Wu, J.-H. (2018). Effects of heat treatment on the chemical compositions and thermal decomposition kinetics of Japanese cedar and beech wood. Polymer Degradation and Stability, 158, 220-227. doi: https://doi.org/10.1016/j.polymdegradstab.2018.11.003

3. Bhowmik, R. N., Venkata Siva, K., Reddy, V. R., Sinha, A. K. (2019). Study of the lattice structure and magnetic spin order modification in chemical routed $\alpha$-Fe1.4Cr0.6O3 oxide as an effect of heat treatment. Journal of Magnetism and Magnetic Materials, 484, 42-54. doi: https://doi.org/10.1016/j.jmmm.2019.03.126

4. Markov, O., Zlygoriev, V., Gerasimenko, O., Hrudkina, N., Shevtsov, S. (2018). Improving the quality of forgings based on upsetting the workpieces with concave facets. Eastern-European Journal of Enterprise Technologies, 5 (1 (95)), 16-24. doi: https:// doi.org/10.15587/1729-4061.2018.142674

5. Karpov, L. P. (2003). Primenenie dvoynoy himiko-termicheskoy obrabotki pri izgotovlenii rezhushchego instrumenta iz konstruktsionnyh staley. Metallovedenie i termicheskaya obrabotka metallov, 1, 7-8.

6. Markov, O., Gerasimenko, O., Aliieva, L., Shapoval, A. (2019). Development of the metal rheology model of high-temperature deformation for modeling by finite element method. EUREKA: Physics and Engineering, 2, 52-60. doi: https://doi.org/10.21303/ $2461-4262.2019 .00877$

7. Stepanov, M. S. (2007). The structure and phase composition of a diffusion layer of alloyed pm steel at lowtemperature diffusion saturation by nitrogen and carbon. Vestnik Donskogo gosudarstvennogo tehnicheskogo universiteta, 7 (1), 39-46.

8. Markov, O. E., Perig, A. V., Zlygoriev, V. N., Markova, M. A., Kosilov, M. S. (2017). Development of forging processes using intermediate workpiece profiling before drawing: research into strained state. Journal of the Brazilian Society of Mechanical Sciences and Engineering, 39 (11), 4649-4665. doi: https://doi.org/10.1007/s40430-017-0812-y 
9. D’yachenko, Yu. G. (2014). Issledovanie iznosostoykogo poverhnostnogo sloya uglerodistoy stali U7 poluchennogo pri himikotermicheskoy obrabotke. Visnyk Donbaskoi derzhavnoi mashynobudivnoi akademiyi, 1, 71-74.

10. Kang, Y., Guo, F., Li, M. (2019). Effect of chemical composition and heat treatment on microstructure and mechanical properties of Nb-xTi-16Si-3Cr-3Al-2Hf-yZr alloy. Materials Science and Engineering: A, 760, 118-124. doi: https://doi.org/10.1016/ j.msea.2019.05.117

11. Liu, X. Y., Yi, H., Che, J. W., Liang, G. Y. (2019). Phase, compositional, structural, and chemical stability of La2Ce2O7 after high temperature heat treatment. Ceramics International, 45 (4), 5030-5035. doi: https://doi.org/10.1016/j.ceramint.2018.11.204

12. Pettinari-Sturmel, F., Vultos, W., Hantcherli, M., Warot-Fonrose, B., Marcelot, C., Douin, J. et. al. (2019). Creep behavior in the new AD730TM nickel-based disk superalloy - Influence of aging heat treatment and local chemical fluctuations. Materials Science and Engineering: A, 754, 9-17. doi: https://doi.org/10.1016/j.msea.2019.02.088

13. Chung, J., Kwak, S.-Y. (2018). Solvent-assisted heat treatment for enhanced chemical stability and mechanical strength of metaaramid nanofibers. European Polymer Journal, 107, 46-53. doi: https://doi.org/10.1016/j.eurpolymj.2018.07.051

14. Liu, X., Zhao, G., Lei, L., Jia, J. (2018). The effect of heat treatment temperature on superconductivity of Bi-2212/YBCO heteroepitaxial structure fabricated by chemical solution deposition approach. Ceramics International, 44 (9), 10820-10823. doi: https:// doi.org/10.1016/j.ceramint.2018.03.126

15. Bruton, T. A., Sedlak, D. L. (2018). Treatment of perfluoroalkyl acids by heat-activated persulfate under conditions representative of in situ chemical oxidation. Chemosphere, 206, 457-464. doi: https://doi.org/10.1016/j.chemosphere.2018.04.128 